\title{
Examining Motivation and Perception of Visitors at Lekki Conservation Centre (LCC) in Nigeria
}

\author{
Folusade C. Arowosafe (B. Tech, M. Tech, PhD) \\ Olalekan A. Tunde-Ajayi (B. Tech, M. Tech) \\ Bola D. Ojo (B. Tech) \\ Department of Ecotourism and Wildlife Management \\ Federal University of Technology, Akure
}

Doi:10.19044/esj.2020.v16n29p192 URL:http://dx.doi.org/10.19044/esj.2020.v16n29p192

\begin{abstract}
People are driven to take up various actions due to motivation. The study examined the motivation and perception of visitors as well as examining the future behavioural intentions of the visitors at Lekki Conservation Centre (LCC), Lagos state, Nigeria. The study employed self-administered questionnaire to obtain information from the visitors. Random sampling method was used to select a total of 200 visitors involved in the survey. Data obtained were analyzed using Statistical Package for Social Sciences (SPSS 21) and results were presented descriptively and inferentially. Results obtained indicated that attractions such as canopy walkway, games served as pullattractions for the visitors to the site while adventure, sightseeing, relaxation and rest were highly ranked as push-motivations for the visitors to the site. The visitors also perceived the site experience as a satisfactory one while affirming they would revisit and recommend the site to other. Chi square analysis revealed a significant relationship between visitors' motivation and perception $(\mathrm{p}=0.000)$. The site posed minimal challenges for visitation and as such is a good place to visit as it affords visitors an entertaining and satisfactory experience. Motivation study is important for tourist sites to improve their competitiveness in the market as it facilitates improvement of visitors' satisfaction.
\end{abstract}

Keywords: Behavioural intention, Motivation, Perception

\section{Introduction}

Tourism is presently one of the most prominent and rapidly improving sectors all around the globe. For years, tourism has experienced increasing levels of growth and development making the industry one of the fastest growing economic segments around the world (UNWTO, 2013). The industry 
has improved drastically over the years, with international tourist arrivals recorded as 1.4 billion for 2018, thereby making up for a total of $5 \%$ of global economic growth for that year (UNWTO, 2019). In addition, the tourism industry births new segments as the years pass by. A prominent segment is nature-based tourism; which is developing and growing more quickly (10$30 \%$ per annum) than tourism in general (Nyaupane et al., 2004). Most people believe that the upward surge in nature-based tourism is due to the fact that contemporary tourists are more demanding and seeking new, enjoyable and unusual experiences (Machnik, 2013). Since there is a rise in tourists' interest in nature-based tourism, research on nature-based tourism is becoming more recognized (Line and Costen, 2011). Nature-based tourism is described as activities which depend on the natural environment (Mehmetoglu, 2007a); depicting that these activities would not be able to exist on their own if not for tourism's occurrence within natural environments with the main focus on nature and natural environments' protection (Newsome and Moore, 2002). Furthermore, Fredman and Tyrväinen (2010) described nature-based tourism as utilizing time in nature outside the confines of tourists' home.

Tourism activity depends upon and relates with a diverse range of tourist behaviors and both the internal and external factors that cause or stimulate these behaviours. This tourism industry is dynamic and involves travelling for leisure purposes, rest, family and friend visitation, pilgrimages and other activities (Yousaf et al., 2018). Simkova and Holzner (2014) report that tourists' travel patterns are closely linked to psychological patterns and this can be used to investigate the factors motivating tourists to travel. People are driven to take up various actions due to a psychological force called motivation (Schiffman and Kanuk, 2003). In the tourism context, motivation involves a body of wants which drives or inspires people to tourist activities and tourism destinations eventually (Beerli and Martín, 2004). This motivation concept is referred to as travel motivation, which connotes the totality of biological and sociocultural forces that energizes, inspires and gives birth to tourists' behavior (Mohammad and Som, 2010; Pearce, 2014). Travel motivation studies has been an essential concept in tourism theoretical development (Mohammad \& Som, 2010) and also tourism destination as well as market studies (Beerli and Martín, 2004).

Push and Pull motivation factors apply to all form of tourists including nature-based tourists (Chen and Mo, 2014). In diverse environmental settings, tourists exhibit different origins and impacts of motivations ((Mehmetoglu and Normann, 2013), thereby making tourism destination managers aware of destination site improvements and inspiring them on effective decisionmaking (Chan and Baum, 2007). Researchers all over the world have utilized travel motivation to investigate and determine visitors' satisfaction level ( Lemmetynen et al., 2016; Celik and Dedeoglu, 2019; Preko et al., 2019), 
predict levels of involvement in recreation (Yan and Halpenny, 2019), reveal travel patterns (Cavagnaro and Staffieri, 2015), comprehend circumstances surrounding tourists' decisions during travel and consumption behavior (Chang et al., 2015) and also to develop more efficient strategies and policies to increase and improve demand for tourism ( Papatheodorou, 2006). The complexity in the nature of this concept has encouraged many researchers to identify diverse travel motives. Push and pull motives have emerged as the central theme which travel motives depend upon. Push and pull factors have therefore been widely used to assess tourists' travel motivations (Michael et al., 2017; Wijaya et al., 2018). This study thus aimed to investigate motivation factors of visitors to Lekki Conservation centre, Lagos state, Nigeria.

\section{Study Area}

The study was carried out in Lekki Conservation Center (LCC). Lekki Conservation Center is one of Nigerian Conservation Foundations' (NCF) foremost conservation projects. LCC is located in Lekki on the Lekki-Epe Expressway in Eti Osa Local Government Area of Lagos State, Nigeria. Lekki Conservation Center is a 78-hectare land area lying between Latitude $6^{0} 27^{\prime} \mathrm{N}$ and $3^{0} 23^{\prime} \mathrm{E}$.

\section{Materials and Method}

The population of this study was visitors to Lekki Conservation Centre (LCC) between January and July, 2019. Two hundred (200) visitors that were willing to participate were chosen for the study. The data collection instrument for this study was a structured questionnaire targeted randomly at the visitors of the site. The questionnaire was divided into three sections. First section captured the demographic characteristics of the visitors; second section captured the travel characteristics of the visitors while the third section captured the visitors' motivation, perception and challenges in visiting the site which were measured using five point likert scale (Strongly agree, Agree, Undecided, Disagree, Strongly Disagree). The copies of questionnaire were filled, returned and analysed using statistical package of social sciences (SPSS 21) and results were presented descriptively using tables (frequencies, percentages, means) and inferentially using chi square.

\section{Results}

Table 1 presents the demographic characteristics of the respondents at Lekki Conservation Centre (LCC). Highest percentage of the respondents were within the youthful and young age of 26-35 years (35.5\%) as youths have more energy to participate in recreational activities than the aged. Highest percentage of the respondents were females $(54.5 \%)$, single $(55.5 \%)$, Nigerian $(91 \%)$ and had attained tertiary level of education $(83.5 \%)$ which shows they 
were knowledgeable enough to participate in the survey effectively. The overwhelming number of respondents living within Lagos $(78.5 \%)$ could be attributed to the tourists site being situated within Lagos. Also, majority of the respondents were Christians (82.5\%), privately employed (29\%) and earned high income of above $\$ 200,000$ (34.5\%).

Table 1: Demographic characteristics of the respondents

\begin{tabular}{|c|c|c|}
\hline Variables & Frequency $(\mathrm{N}=200)$ & Percentage (\%) \\
\hline \multicolumn{3}{|l|}{ Age } \\
\hline $11-25$ years & 60 & 30 \\
\hline $26-35$ years & 70 & 35.5 \\
\hline $36-45$ years & 47 & 23.5 \\
\hline $46-55$ years & 16 & 8 \\
\hline $\begin{array}{l}56 \text { years \& } \\
\text { Above }\end{array}$ & 7 & 3.5 \\
\hline \multicolumn{3}{|l|}{ Gender } \\
\hline Male & 91 & 45.5 \\
\hline Female & 109 & 54.5 \\
\hline \multicolumn{3}{|c|}{ Marital status } \\
\hline Single & 111 & 55.5 \\
\hline Married & 84 & 42 \\
\hline Divorced & 5 & 2.5 \\
\hline \multicolumn{3}{|l|}{$\begin{array}{l}\text { Educational } \\
\text { level }\end{array}$} \\
\hline $\begin{array}{l}\text { Primary } \\
\text { Education }\end{array}$ & 9 & 4.5 \\
\hline $\begin{array}{l}\text { Secondary } \\
\text { Education }\end{array}$ & 24 & 12 \\
\hline $\begin{array}{l}\text { Tertiary } \\
\text { Education }\end{array}$ & 167 & 83.5 \\
\hline \multicolumn{3}{|l|}{ Nationality } \\
\hline Nigerian & 182 & 91 \\
\hline Foreigner & 18 & 9 \\
\hline \multicolumn{3}{|l|}{$\begin{array}{l}\text { Place of } \\
\text { residence }\end{array}$} \\
\hline within Lagos & 157 & 78.5 \\
\hline Others & 43 & 21.5 \\
\hline \multicolumn{3}{|l|}{ Religion } \\
\hline Christianity & 165 & 82.5 \\
\hline Islam & 31 & 15.5 \\
\hline
\end{tabular}




\begin{tabular}{|c|c|c|}
\hline Others & 4 & 2 \\
\hline \multicolumn{3}{|l|}{$\begin{array}{l}\text { Income Per } \\
\text { Month }\end{array}$} \\
\hline$\leq ¥ 49,000$ & 8 & 4 \\
\hline $\begin{array}{l}\$ 50,000- \\
\$ 99,000\end{array}$ & 45 & 22.5 \\
\hline $\begin{array}{l}¥ 100,000- \\
¥ 149,000\end{array}$ & 52 & 26 \\
\hline $\begin{array}{l}\$ 150,000- \\
\$ 199,000\end{array}$ & 26 & 13 \\
\hline$\geq £ 200,000$ & 69 & 34.5 \\
\hline \multicolumn{3}{|l|}{ Occupation } \\
\hline Civil Servant & 34 & 17 \\
\hline Self-employed & 57 & 28.5 \\
\hline Students & 50 & 25.5 \\
\hline Private & 58 & 29 \\
\hline Unemployed & 1 & 0.5 \\
\hline
\end{tabular}

Table 2 presents the travel characteristics of the visitors to reveal that majority were first time visitors (73\%) and that majority of the visitors travelled with their family members $(38.5 \%)$. Also, majority of the visitors spent around three hours $(75 \%)$ at the tourist site while most of the visitors got to know about the site through their friends and relatives (58\%).

Table 2: Travel characteristics of respondents

\begin{tabular}{lcc}
\hline Variables & Frequency $(\mathbf{N = 2 0 0})$ & Percentage (\%) \\
\hline Number of Visits & & \\
First time & 146 & 73 \\
Twice & 36 & 18 \\
Thrice & 10 & 5 \\
More than thrice & 8 & 4 \\
Visitation Group & & \\
Alone & 31 & 15.5 \\
With Spouse & 35 & 17.5 \\
With Family & 77 & 38.5 \\
With Friends & 44 & 22 \\
With Tour Group & 13 & 6.5 \\
Length of Tourist Visit & & \\
Less than 3 hours & 5 & 2.5 \\
\hline
\end{tabular}




\begin{tabular}{lcc}
\hline 3 hours & 150 & 75 \\
$\begin{array}{l}\text { More than } 3 \text { hours } \\
\text { Source of } \\
\text { awareness } \\
\begin{array}{l}\text { I already knew } \\
\text { about it }\end{array}\end{array}$ & 45 & 22.5 \\
$\begin{array}{l}\text { Friends and } \\
\text { relatives }\end{array}$ & 49 & 24.5 \\
Internet & 116 & 58 \\
Tv & 27 & 13.5 \\
Radio & 2 & 1 \\
Others & 4 & 2 \\
\hline
\end{tabular}

Table 3 reveals the attractive features present at Lekki Conservation Centre (LCC) and the rate at which it attracted the visitors to the site. Majority of the visitors were attracted to the site because of canopy walkway (40\%) which is the longest canopy walkway in Africa. Also, a substantial number of the visitors were attracted because of the games (25\%) available at the site, some were attracted because of animal viewing (13\%), tree house (13\%). Other attractive features include fish pond, nature station, jungle trek.

Table 3: Features that attracts tourist to visit LCC

\begin{tabular}{lcc}
\hline Attractive Features & Frequency $(\mathbf{N}=\mathbf{2 0 0})$ & Percentage (\%) \\
\hline Playing Games & 50 & 25 \\
Animal viewing & 26 & 13 \\
Canopy walk & 80 & 40 \\
Fish Pond & 10 & 5 \\
Tree house & 26 & 13 \\
Nature Station & 4 & 2 \\
Jungle trek & 3 & 1.5 \\
All of the above & 1 & 0.5 \\
\hline
\end{tabular}

Table 4 presents the various factors that facilitate visit to Lekki Conservation Centre as opined by the visitors. Majority of the visitors visited for adventure (Mean=4.53), sightseeing $($ Mean= 4.51) and for relaxation and rest purpose $($ Mean $=4.42)$.

Table 4: Factors motivating to visitors to visit LCC

\begin{tabular}{lcccccccc}
\hline Factors & SA & $\begin{array}{c}\mathbf{A} \\
(\boldsymbol{\%})\end{array}$ & $\begin{array}{c}\mathbf{U} \\
(\boldsymbol{\%})\end{array}$ & $\begin{array}{c}\mathbf{D} \\
(\boldsymbol{\%})\end{array}$ & $\begin{array}{c}\text { SD } \\
(\boldsymbol{\%})\end{array}$ & Mean & $\begin{array}{c}\text { Std } \\
\text { Dev }\end{array}$ & Rank \\
\hline Adventure & 119 & 73 & 3 & 4 & 1 & 4.53 & 0.68 & 1 \\
\hline
\end{tabular}




\begin{tabular}{|c|c|c|c|c|c|c|c|c|}
\hline & $(59.5)$ & $(36.5)$ & $(1.5)$ & $(2.0)$ & $(0.5)$ & & & \\
\hline Sight seeing & $\begin{array}{c}114 \\
(57.0)\end{array}$ & $\begin{array}{c}77 \\
(38.5)\end{array}$ & $\begin{array}{c}6 \\
(3.0)\end{array}$ & $\begin{array}{c}3 \\
(1.5)\end{array}$ & $\begin{array}{c}0 \\
(0.0)\end{array}$ & 4.51 & 0.63 & 2 \\
\hline Relaxation and rest & $\begin{array}{c}108 \\
(54.0)\end{array}$ & $\begin{array}{c}81 \\
(40.5)\end{array}$ & $\begin{array}{c}3 \\
(1.5)\end{array}$ & $\begin{array}{c}2 \\
(1.0)\end{array}$ & $\begin{array}{c}6 \\
(3.0)\end{array}$ & 4.42 & 0.83 & 3 \\
\hline Change environment & $\begin{array}{c}107 \\
(53.5)\end{array}$ & $\begin{array}{c}71 \\
(35.5)\end{array}$ & $\begin{array}{c}8 \\
(4.0)\end{array}$ & $\begin{array}{c}10 \\
(5.0)\end{array}$ & $\begin{array}{c}4 \\
(2.0)\end{array}$ & 4.34 & 0.92 & 4 \\
\hline $\begin{array}{l}\text { Facilitation of social } \\
\text { interaction }\end{array}$ & $\begin{array}{c}83 \\
(41.5)\end{array}$ & $\begin{array}{c}77 \\
(38.5)\end{array}$ & $(11.0)$ & $\begin{array}{c}11 \\
(5.5)\end{array}$ & $\begin{array}{c}7 \\
(3.5)\end{array}$ & 4.09 & 1.03 & 5 \\
\hline $\begin{array}{l}\text { Education purpose (Learning } \\
\text { and research) }\end{array}$ & $(41.0)$ & $\begin{array}{c}49 \\
(24.5)\end{array}$ & $(9.0)$ & $\begin{array}{c}26 \\
(13.0)\end{array}$ & $\begin{array}{c}25 \\
(12.5)\end{array}$ & 3.69 & 1.43 & 6 \\
\hline Escape from work & $\begin{array}{c}25 \\
(12.5)\end{array}$ & $\begin{array}{c}33 \\
(16.5) \\
\end{array}$ & $\begin{array}{c}19 \\
(9.5)\end{array}$ & $\begin{array}{c}61 \\
(30.5)\end{array}$ & $\begin{array}{c}62 \\
(31.0)\end{array}$ & 2.49 & 1.40 & 7 \\
\hline \multicolumn{9}{|c|}{$\begin{array}{l}\text { Keys: SA- Strongly Agree, A- Agree, U- Undecided, D- Disagree, SD- Strongly Disagree } \\
\text { Table } 5 \text { presents the visitors' perception about the site. The visitors opined that } \\
\text { they would definitely revisit the site }(\mathrm{Mean}=4.46) \text {, they would definitely } \\
\text { recommend the site to others (Mean=4.36). They also opined that the visit } \\
\text { experience was a satisfactory one (Mean=4.36). } \\
\text { Table 5: Visitors' perception of LCC experience }\end{array}$} \\
\hline Factors & $\begin{array}{l}\text { SA } \\
(\%)\end{array}$ & $\begin{array}{c}\mathrm{A} \\
(\%)\end{array}$ & $\begin{array}{c}\mathrm{U} \\
(\%)\end{array}$ & $\begin{array}{c}\mathrm{D} \\
(\%)\end{array}$ & $\begin{array}{l}\text { SD } \\
(\%)\end{array}$ & Mean & $\begin{array}{l}\text { Std } \\
\text { Dev }\end{array}$ & Rank \\
\hline I will d & $\begin{array}{c}106 \\
(54.5)\end{array}$ & $\begin{array}{c}80 \\
(33.0)\end{array}$ & $\begin{array}{c}13 \\
(7.5)\end{array}$ & $\begin{array}{c}1 \\
(4.0)\end{array}$ & $\begin{array}{c}0 \\
(1.0)\end{array}$ & 4.46 & 0.64 & 1 \\
\hline $\begin{array}{l}\text { I will definitely recommend this } \\
\text { center to others }\end{array}$ & $\begin{array}{c}109 \\
(53.0)\end{array}$ & $\begin{array}{c}66 \\
(40.0)\end{array}$ & $\begin{array}{l}15 \\
(6.5)\end{array}$ & $\begin{array}{c}8 \\
(0.5)\end{array}$ & $\begin{array}{c}2 \\
(0.0)\end{array}$ & 4.36 & 0.86 & 2 \\
\hline $\begin{array}{l}\text { The visit experience was a } \\
\text { satisfactory one }\end{array}$ & $\begin{array}{c}94 \\
(47.0)\end{array}$ & $\begin{array}{c}88 \\
(44.0)\end{array}$ & $\begin{array}{c}15 \\
(7.5)\end{array}$ & $\begin{array}{c}2 \\
(1.0)\end{array}$ & $\begin{array}{c}1 \\
(0.5)\end{array}$ & 4.36 & 0.71 & 3 \\
\hline $\begin{array}{l}\text { The environment was well } \\
\text { maintained and attractive }\end{array}$ & $\begin{array}{c}99 \\
(49.5)\end{array}$ & $\begin{array}{c}79 \\
(39.5)\end{array}$ & $\begin{array}{c}15 \\
(7.5)\end{array}$ & $\begin{array}{c}6 \\
(3.0)\end{array}$ & $\begin{array}{c}1 \\
(0.5)\end{array}$ & 4.35 & 0.79 & 4 \\
\hline $\begin{array}{l}\text { The visit was more entertaining } \\
\text { than educational }\end{array}$ & $\begin{array}{c}94 \\
(47.0)\end{array}$ & $\begin{array}{c}80 \\
(40.0)\end{array}$ & $\begin{array}{c}15 \\
(7.5)\end{array}$ & $\begin{array}{c}9 \\
(4.5)\end{array}$ & $\begin{array}{c}2 \\
(1.0)\end{array}$ & 4.28 & 0.86 & 5 \\
\hline $\begin{array}{l}\text { The quality of service was } \\
\text { satisfactory }\end{array}$ & $\begin{array}{c}85 \\
(42.5)\end{array}$ & $\begin{array}{c}90 \\
(45.0)\end{array}$ & $\begin{array}{c}16 \\
(8.0)\end{array}$ & $\begin{array}{c}7 \\
(3.5)\end{array}$ & $\begin{array}{c}2 \\
(1.0)\end{array}$ & 4.25 & 0.82 & 6 \\
\hline Price for tickets was reasonable & $\begin{array}{c}84 \\
(42.0)\end{array}$ & $\begin{array}{c}66 \\
(33.0)\end{array}$ & $\begin{array}{c}23 \\
(11.5)\end{array}$ & $\begin{array}{c}18 \\
(9.0)\end{array}$ & $\begin{array}{c}9 \\
(4.5)\end{array}$ & 3.99 & 1.14 & 7 \\
\hline $\begin{array}{l}\text { The visit was more educational } \\
\text { than entertaining }\end{array}$ & $\begin{array}{c}63 \\
(31.5)\end{array}$ & $\begin{array}{c}44 \\
(22.0)\end{array}$ & $\begin{array}{c}29 \\
(14.5)\end{array}$ & $\begin{array}{c}32 \\
(16.0)\end{array}$ & $\begin{array}{c}32 \\
(16.0)\end{array}$ & 3.37 & 1.46 & 8 \\
\hline
\end{tabular}

Keys: SA- Strongly Agree, A- Agree, U- Undecided, D- Disagree, SD- Strongly Disagree

Table 6 presents the potential challenges of visitors to Lekki Conservation Centre. The relatively low mean value of the variables shows that the visitors 
disagreed that they had challenges in visiting the site although high entrance fee had the highest mean value of 2.38 .

Table 6: Challenges of visit to LCC

\begin{tabular}{|c|c|c|c|c|c|c|c|c|}
\hline Factors & $\begin{array}{l}\text { SA } \\
(\%)\end{array}$ & $\begin{array}{c}A \\
(\%)\end{array}$ & $\begin{array}{c}\mathrm{U} \\
(\%)\end{array}$ & $\begin{array}{l}\mathrm{D} \\
(\%)\end{array}$ & $\begin{array}{l}\text { SD } \\
(\%)\end{array}$ & Mean & $\begin{array}{l}\text { Std } \\
\text { Dev }\end{array}$ & Rank \\
\hline High Entrance fee & $\begin{array}{c}24 \\
(12.0)\end{array}$ & $\begin{array}{c}20 \\
(10.0)\end{array}$ & $\begin{array}{c}25 \\
(12.5)\end{array}$ & $\begin{array}{c}69 \\
(34.5)\end{array}$ & $\begin{array}{c}62 \\
(31.0)\end{array}$ & 2.38 & 1.34 & 1 \\
\hline $\begin{array}{l}\text { Location (too far from your } \\
\text { residence) }\end{array}$ & $\begin{array}{c}11 \\
(5.5)\end{array}$ & $\begin{array}{c}27 \\
(13.5)\end{array}$ & $\begin{array}{c}16 \\
(8.0)\end{array}$ & $\begin{array}{c}71 \\
(35.5)\end{array}$ & $\begin{array}{c}75 \\
(37.5)\end{array}$ & 2.14 & 1.22 & 2 \\
\hline Inadequate medical aid & $\begin{array}{c}7 \\
(3.5)\end{array}$ & $\begin{array}{c}11 \\
(5.5)\end{array}$ & $\begin{array}{c}31 \\
(15.5)\end{array}$ & $\begin{array}{c}74 \\
(37.0)\end{array}$ & $\begin{array}{c}77 \\
(38.5)\end{array}$ & 1.99 & 1.04 & 3 \\
\hline Bad road & $\begin{array}{c}3 \\
(1.5)\end{array}$ & $\begin{array}{c}18 \\
(9.0)\end{array}$ & $\begin{array}{c}11 \\
(5.5)\end{array}$ & $\begin{array}{c}79 \\
(39.5)\end{array}$ & $\begin{array}{c}89 \\
(44.5)\end{array}$ & 1.84 & 0.99 & 4 \\
\hline $\begin{array}{l}\text { Unfavourable weather } \\
\text { condition }\end{array}$ & $\begin{array}{c}5 \\
(2.5)\end{array}$ & $\begin{array}{c}13 \\
(6.5)\end{array}$ & $\begin{array}{c}13 \\
(6.5)\end{array}$ & $\begin{array}{c}86 \\
(43.0)\end{array}$ & $\begin{array}{c}83 \\
(41.5)\end{array}$ & 1.86 & 0.97 & 5 \\
\hline Overcrowding & $\begin{array}{c}4 \\
(2.0)\end{array}$ & $\begin{array}{c}12 \\
(6.0)\end{array}$ & $\begin{array}{c}17 \\
(8.5)\end{array}$ & $\begin{array}{c}80 \\
(40.0)\end{array}$ & $\begin{array}{c}87 \\
(43.5)\end{array}$ & 1.83 & 0.96 & 6 \\
\hline $\begin{array}{l}\text { Quality of service (Unhelpful } \\
\text { staff) }\end{array}$ & $\begin{array}{c}4 \\
(2.0)\end{array}$ & $\begin{array}{c}11 \\
(5.5)\end{array}$ & $\begin{array}{c}14 \\
(7.0)\end{array}$ & $\begin{array}{c}79 \\
(39.5)\end{array}$ & $\begin{array}{c}92 \\
(46.0)\end{array}$ & 1.78 & 0.94 & 7 \\
\hline Too much pollution/ litter & $\begin{array}{c}8 \\
(4.0)\end{array}$ & $\begin{array}{c}9 \\
(4.5)\end{array}$ & $\begin{array}{c}10 \\
(5.0)\end{array}$ & $\begin{array}{c}71 \\
(35.5)\end{array}$ & $\begin{array}{c}102 \\
(51.0)\end{array}$ & 1.75 & 1.02 & 8 \\
\hline
\end{tabular}

Keys: SA- Strongly Agree, A- Agree, U- Undecided, D- Disagree, SD- Strongly Disagree

Table 7 shows the chi square of relationship between visitors' travel characteristics, perception and motivation. There is a significant relationship between visitors' motivation and perception $(\mathrm{p}=0.000)$, visitors' motivation and number of visit $(\mathrm{p}=0.000)$, visitors, motivation and source of awareness $(p=0.003)$.

Table 7: Relationship between travel characteristics, visitors' perception and visitors' motivation

\begin{tabular}{lccc}
\hline Hypotheses & Chi Square $\left(\chi^{2}\right)$ value & Sig. & Decision \\
\hline Motivation*Perception & 536.336 & 0.000 & $*$ \\
Motivation*Number of visit & 160.494 & 0.000 & $*$ \\
Motivation*Visitation group & 91.050 & 0.115 & NS \\
Motivation*Source of awareness & 137.923 & 0.003 & $*$ \\
\hline
\end{tabular}

\section{Discussion}

$$
\mathrm{P}<0.05 \text {, *-significant, NS- Not significant }
$$

Highest percentage of the visitors were within youthful age of 26-35 years which shows they are within their active age for recreational activities as Age is reported to have positive influence on individual's desire for relaxation and nature exploration (Ma et al., 2018). Richards (2015) also confirmed that there is an increase in the number of youth tourists and that young people in many countries around the world have recently acquired more 
purchasing power. Also, majority of the visitors were females which is contradictory to the assertion that men are more likely to participate in adventure activities (Xie et al., 2008). Furthermore, highest percentage of the visitors were Nigerians and singles living within the destination's city which shows they did not have to travel far to get in order to visit the tourist destination as supported by Biearnat and Lubowiecki-Vikuk (2012) that singles prefer shorter but frequent trips. Most of the visitors were also employed and earning high income which is a clear indication they could afford recreational activities' cost.

The visitors were mostly first time visitors who had travelled with their family and friends to spend few hours at the site. This is consistent with Chan et al. (2018) who found out in his study that companions during visits were family and friends. The major source of awareness of this tourist site was through friends and relatives meaning a positive word of mouth from friends and relatives has an effect on a potential visit to a destination as supported by Veiga et al. (2017) that travellers depend on their peers' appreciation when forming their own opinions and making travel decisions, often using reviews as a crucial complement to decision-making.

Lekki Conservation centre possesses a lot of great attractions capable of entertaining visitors which includes canopy walkway, nature station, fish pond, animal viewing, games, tree house, jungle trek. These attractions contribute to the good destination image of the site attracting both local and foreign visitors. Canopy walkway which is an attraction at the site was responsible for the visit of most of the visitors during this study. These attractions pull visitors to the site and are classified as pull motivations as defined by Pansiri (2014) that pull motivation refers to the supply of the attraction and the characteristics of the destination. Karanth and DeFries (2010) also stated that protected areas and parks are the main visitor attractions of nature-based tourist attractions across countries. Adventure, sightseeing, relaxation and rest were highly ranked as factors motivating the visitors to visit the site as this site offers facilities that encourage such activities. Williams and Baláž (2015) support this assertion by stating that some young adventure tourists look for risk and adventure to reinforce their identity or simply because of sensation seeking. Todorovic and Jovicic (2016) also argued that the main reason for embarking on holidays is that visitors look for a break from their usual schedule and settings that allow them to relax and lessen mental fatigue.

The visitors finally claimed their experience was a satisfactory one and that they would revisit and recommend the site to others and this is in line with Said and Maryono (2018) that factors which influence visitors to visit a destination are the attitude towards the destination, the opinion from relatives and friends, experience from previous travelling. Lai et al. (2010) also stated 
that the level of satisfaction causes the intention to come back to the destination. The relatively low mean values of the challenges to visitation at the site shows the site has good destination image and the management of the site are working effectively to satisfy their visitors by limiting encounter of problems in visiting the site. This is in line with Voase (2012) who stated that in order to achieve the desired results, the building of a coherent brand image and the way the tourist site is perceived by actual and potential visitors are considered as the principal factors upon which the site's success depends.

\section{Conclusion}

This study aimed to examine the motivation factors and perception of visitors at Lekki Conservation Centre (LCC), Lagos state, Nigeria and concludes that the site has enough attractions to motivate visitors to visit especially the Canopy walkway which is the longest canopy walkway in Africa among other attractions like tree house, animal viewing, games. Some major factors that also push visitors to the site are adventure, sightseeing and relaxation and rest. The visitors further perceived the site as providing satisfactory experience. They also opined they would recommend the site to others while showing revisit intention as the site poses minimal challenges to the visitors.

\section{Limitation and Suggestions for Future Research}

This study was limited to Lekki Conservation Centre alone which is a nature-based tourist site and as such gathered information from nature-based visitors. This study can further be replicated in other forms of tourist sites other than nature-based area so as to obtain more motivation factors for tourists.

\section{References :}

1. Beerli, A., and Martín, J. D. (2004). Factors influencing destination image. Annals of Tourism Research, 31(3), 657-681.

2. Biernat, E. and Lubowiecki-Vikuk, A. (2012), "Tourist activity among urban singles in view of sociodemographic factors. Leisure and recreation", Studies in Physical Culture and Tourism, 19 (2), 86-93.

3. Cavagnaro, E. and Staffieri, S. (2015), "A study of students' travelers values and needs in order to establish future patterns and insights", Journal of Tourism Futures, 1 (2), 94-107.

4. Celik, S. and Dedeoglu, B.B. (2019), "Psychological factors affecting the behaviour intention of the tourist visiting Southeastern Anatolia", Journal of Hospitality and Tourism Insights, 2 (4), 425-450.

5. Chan Chung-Shing, Siu Kan Yuen, Xialei Duan and Lawal M. Marafa (2018) An analysis of push-pull motivations of visitors to Country 
Parks in Hong Kong, World Leisure Journal, 60 (3), 191-208, DOI: 10.1080/16078055.2018.1496527

6. Chan, J. L., and Baum, T. (2007). Motivation factors of ecotourists in ecolodge accommodation: The push and pull factors. Asia Pacific Journal of Tourism Research, 12(4), 349-364.

7. Chang, L., Yeh, N. and Tung, T. (2015), "How do motivation, pre-visit information search, and destination image affect post visit behaviour intentions?, the case of an Island destination", European Journal of Tourism Research, 9, 8-23.

8. Chen, Y., and Mo, H. (2014). A survey of push and pull motivations of green event tourists. International Journal of Information and Education Technology, 4(3), 260-263.

9. Fredman, P., and Tyrväinen, L. (2010). Frontiers in Nature-Based Tourism. Scandinavian Journal of Hospitality \& Tourism, 10(3), 177189. doi: 10.1080/15022250.2010.502365

10. Karanth, and DeFries. (2010). Nature-based tourism in Indian protected areas: New challenges for park management. Conservation Letters, 4(2), 137-149.

https://onlinelibrary.wiley.com/doi/abs/10.1111/j.1755263X.2010.00154.X

11. .Lai, C.-N Yu, T.-K., and J.-K. Kuo (2010). Social Behavior and Personality: An International Journal, 38(4), 509-514.

12. Lemmetyinen, A., Dimitrovski, D., Nieminen, L. and Pohjola, T. (2016). "Cruise destination brand awareness as a moderator in motivation-satisfaction relation". Tourism Review, 71 (4), 245-258.

13. Line, N., and Costen, W. (2011). Environmental attitudes, motivation, and

attachment: Toward a model of nature-based tourism. Paper presented at the International CHRIE Conference-Refereed Track.

14. Ma, A., Chow, A., Cheung, L., Lee, K. and Liu, S. (2018), "Impacts of tourists' socio-demographic characteristics on the travel motivation and satisfaction: the case of protected areas in South China", Sustainability, 10 (10), 3388.

15. Machnik, A. (2013). Nature Based Tourism as an Introduction to Ecotourism Experience - A New Approach. Journal of Tourism Challenges \& Trends, 6(1), 75.

16. Mehmetoglu, M. (2007a). Nature-Based Tourism: A Contrast to Everyday Life. Journal of Ecotourism, 6(2), 111.

17. Mehmetoglu, M., and Normann, Ø. (2013). The link between travel motives and activities in naturebased tourism. Tourism Review of AIEST - International Association of Scientific Experts in Tourism, $68(2), 3-13$. 
18. Michael, N., Wien, C. and Reisinger, Y. (2017), "Push and pull escape travel motivations of Emirati nationals to Australia", International Journal of Culture, Tourism and Hospitality Research, 11 (3), 274296.

19. Mohammad, B. A., and Som, A. P. (2010). An analysis of push and pull travel motivations of foreign tourists to Jordan. International Journal of Business and Management, 5(12), 41-50.

20. Newsome, D., and Moore, S. (2002). Natural Area Tourism: Ecology, Impacts and Management. Channel View Publications. UK.

21. Nyaupane, G. P., Morais, D. B., and Graefe, A. R. (2004). Nature Tourism Constraints: A Cross-Activity Comparison. Annals of Tourism Research, 31(3), 540. doi: 10.1016/j.annals.2004.01.006

22. Pansiri, J. (2014). Tourist motives and destination competitiveness: A gap analysis perspective. International Journal of Hospitality \& Tourism Administration, 15(3), 217-247.

23. Papatheodorou, A. (2006), Managing Tourism Destinations, Edward Elgar Publishers, Northampton.

24. Pearce, P. L. (2014). Tourism motivations and decision making. In A. A. Lew, C. M. Hall, and A. M. Williams (Eds.), The Wiley Blackwell companion to tourism (pp. 45-54). Chichester, West Sussex;Malden, MA: Wiley Blackwell.

25. Preko, A., Doe, F. and Dadzie, S.A. (2019), "The future of youth tourism in Ghana: motives, satisfaction and behavior intentions", Journal of Tourism Futures, 5 (1), 5-21.

26. Richards, G. (2015), "The new global nomads: Youth travel in a globalizing world", Tourism Recreation Research, 40 (3), 340-352, doi: 10.1080/02508281.2015.1075724

27. Said, J., and Maryono, M. (2018). Motivation and perception of tourists as push and pull factors to visit national park. In E3S Web of Conferences (Vol. 31, p. 08022). EDP Sciences.

28. Schiffman, L. G., and Kanuk, L. L. (2003). Consumer behavior (8th ed.). Upper Saddle River, NJ: Pearson Prentice Hall.

29. Simková, E. and Jindrich, H. (2014), "Motivation of Tourism Participants", Social and Behavioral Sciences, 159, 660 -664. doi.org/10.1016/j.sbspro.2014.12.455

30. Todorovi, N. and Dobrica Jovicic (2016), "Motivational factors of youth tourists visiting Belgrade", CVIJIC, 66 (2), 273-289.

31. UNWTO. (2013). UNWTO Tourism Highlights, 2013 Edition | Tourism Trends and Marketing Strategies UNWTO. From http://mkt.unwto.org/publication/unwtotourism-highlights-2013edition 
32. UNWTO (2019). UNWTO International Tourism Highlights, 2019 edition. International tourism continues to outpace the global economy.

http://www.eunwto.org/doi/book/10.18111/9789284421152

33. Veiga, C., Santos, M., Águas, P. and Santos, J. (2017), "Are millennials transforming global tourism? Challenges for destinations and companies", Worldwide Hospitality and Tourism Themes, 9 (6), 603-616.

34. Voase R. (2012), "Recognition, reputation and response: Some critical thoughts on destinations and brand," in Journal of Destination Marketing \& Management, 1, 78-83.

35. Wijaya, S., Wahyudi, W., Kusuma, C. and Sugiano, E. (2018), "Travel motivation of Indonesian seniors in choosing destination overseas", International Journal of Culture, Tourism and Hospitality Review, 12 (2), 185-197.

36. Williams, A.M. and Baláž, V. (2015), "Tourism Risk and Uncertainty: Theoretical Reflections", Journal of Travel Research, 54 (3), 271-287. doi: $10.1177 / 0047287514523334$

37. Xie, H., Costa, C. and Morais, D. (2008), "Gender differences in rural tourists motivation and activity participation", Journal of Hospitality and Leisure Marketing, 16 (4), 1-27.

38. Yan, N. and Halpenny, E. (2019), "The role of cultural difference and travel motivation in event participation: a cross-cultural perspective", International Journal of Events and Festival Management, 10 (2), 155173.

39. Yousaf, A., Amin, I., C. Santos, J.A. (2018), Tourists' Motivations to Travel: a Theoretical Perspective on the Existing Literature, Tourism and Hospitality Management, 24 (1), 197-211, 010403, https://doi.org/10.20867/thm.24.1.8 